\title{
Changes in the 'Connectedness' and Resilience of Paleolithic Societies in Mediterranean Ecosystems
}

\author{
Mary C. Stiner • Steven L. Kuhn
}

Published online: 21 July 2006

(C) Springer Science+Business Media, Inc. 2006

\begin{abstract}
Human predator-prey relationships changed dramatically in the Mediterranean Basin between 250,000 and 9,000 years ago. Many of these changes can be linked to increases in Paleolithic human population densities. Small game species are particularly diagnostic of increases in human hunting pressure and are a major source of evidence for demographic change after 40-45,000 years ago. Biomass-corrected data on prey choice also indicate increasing use of those species that possess higher reproductive efficiencies. Step-wise, apparently irreversible shifts in human predatory niche are apparent in the Mediterranean Basin, beginning with the earliest Upper Paleolithic in the east and spreading westward. Evidence of demographic pressure and greater use of resilient prey populations is followed by technological innovations to exploit these animals more efficiently. The zooarchaeological findings suggest that Middle and Lower Paleolithic reproductive units probably were not robust at the micropopulation scale, due to the rather narrow set of behavioral responses that characterized social groups at the time, and thus localized extinctions at the micropopulation level were likely to have been common. Upper Paleolithic groups were the quintessential colonizers and, in addition, uniquely good at holding on to habitat gained. Upper Paleolithic archaeological "cultures" had shorter histories of existence than those of earlier periods, but they were even more widespread geographically. The demographic robustness of the Upper Paleolithic systems may stem from wholesale strategies for evening-out or sharing risk and volatility in technology. Micropopulations were larger and often denser on landscapes, more connected via cooperative ties, and thus more robust.
\end{abstract}

Key words Mediterranean Paleolithic $\cdot$ demography $\cdot$ hunting $\cdot$ diet breadth . foraging efficiency $\cdot$ subsistence risk $\cdot$ human evolution.

M. C. Stiner $(\bowtie) \cdot$ S. L. Kuhn

Department of Anthropology, Building 30, University of Arizona, Tucson, AZ 85721-0030, USA

e-mail: mstiner@email.arizona.edu

S. Kuhn

e-mail: skuhn@email.arizona.edu 


\section{Introduction}

There can be no question that the rise of agricultural economies some 10,000 years ago redefined humans' relationship with nature. Such economies greatly amplified the potential of human cultural behavior to reshape ecosystems. Yet the earliest demonstrable impacts of humans on animal and plant communities - and on the nature and resilience of coupled human and natural systems - are traceable to Upper Paleolithic hunter-gatherers some 45,000 years ago or earlier (Tchernov, 1992b). Sometime during the late Pleistocene epoch, more or less concomitant with the spread of anatomically modern Homo sapiens into Eurasia (but not their earliest appearance in Africa or the Levant), we see the evolution of novel technological and social mechanisms for buffering or redistributing environmental risk. These developments resulted in permanent changes in human demographic potentials and the carrying capacities of a wide variety of habitats throughout Eurasia. Even in this early period, there is evidence that human foragers affected the relative abundance of prey species and therefore biotic community composition more generally.

This paper reviews evidence for fundamental changes in the ecology of early humans and human ancestors in Eurasia through the end of the Pleistocene geological epoch (Table I). Direct evidence from food debris and artifacts found in archaeological sites, and indirect evidence pertaining to habitat diversity, demography, and rates of culture change, point to several watershed transitions in hominid-environment relations. Some of the most important shifts involved movement into, and then out of, a rather specialized form of biggame predation. With the appearance of Upper Paleolithic cultures, the very rules of the game seem to have changed. We argue that this more recent set of behavioral and ecological transitions was due largely to changes in the degrees of "connectedness" within human behavioral systems.

\section{Paleolithic Background}

The genus Homo emerged roughly 2.5 million years ago in Africa. The oldest archaeological and fossil remains outside Africa date to roughly 1.8 million years ago or after. Prior to their expansion beyond the African continent, hominids were confined to tropical and subtropical habitats. The spread of early Homo across tropical and subtropical southern Asia may have been comparatively rapid, a least into areas with similar temperature ranges and patterns of resource availability (compare Foley and Lahr, 1997; Gabunia et al., 2000; Gibert, 1992; Goren-Inbar, 1992; Klein, 1999; Mallegni, 1992; Sémah et al., 2000; Stekelis, 1966; Swisher et al., 1994; Tchernov, 1981, 1992a). The earliest

Table I General Chronology of Paleolithic Cultures in Eurasia

(KYA) thousand years ago.

\begin{tabular}{ll}
\hline Paleolithic culture period & Duration \\
\hline Neolithic & $10 \mathrm{KYA}$ or later, depending on region \\
Epi-Paleolithic/Mesolithic & 20 to $10 \mathrm{KYA}$ \\
Upper Paleolithic & $50-35$ to $20 \mathrm{KYA}$ (earliest in Levant, \\
& closest to African continent) \\
Middle Paleolithic & 250 to $30 \mathrm{KYA}$ \\
Lower Paleolithic & 2,600 to $250 \mathrm{KYA}$ \\
\hline
\end{tabular}


known sites outside of Africa occur at relatively low latitudes or in areas with sheltered microclimates, and the available data suggest that populations expanded from south to north much more slowly than they moved west to east. Hominid sites exist but are very rare in temperate and subarctic habitats prior to half a million years ago, and those few that exist seem to date to the warmest interglacial climatic intervals (Dennell and Roebroeks, 1996; Roebroeks, 2005). Clearly, cold environments presented a fundamental barrier to the early expansion of the genus Homo, unlike the tropical and subtropical habitats of southern and eastern Asia. By 500,000 years ago, however, hominids seem to have established a more or less permanent presence in northern habitats, despite the climatic severity of some of these areas (Roebroeks et al., 1992; Rolland, 1998).

Technological and economic changes were necessary prerequisites for the persistence of hominid populations in cold environments. Fire would have enhanced hominids' ability to survive temperate Eurasian winters. Though convincing cases for controlled use of fire before 250,000 years ago (the beginning of the Middle Paleolithic) are very few in number (see Binford and Ho, 1985; Weiner et al., 1998), fire features as old as 350-400,000 years ago may exist (e.g., Kretzoi and Dobosi, 1990).

Perhaps most challenging to the first hominids that spread into Eurasia, however, were the novel variations in seasonality, punctuated in many areas by winters of intense cold and snow-covered or frozen ground. Colonizing populations of Homo could only have survived northern Eurasian winters by exploiting large mammals, as few other foods would have been available to them during the cold season. Nuts and other large seeds, though energyrich, long lasting, and locally common in temperate forests, are relatively expensive to process, and snow cover greatly raises the winter search costs of these resources. Seed and nut hull fragments are occasionally found in Lower and Middle Paleolithic sites (e.g., Barton et al., 1999), but there are no archaeological indications of stockpiled plant foods or the grinding equipment necessary to increase their digestibility. Meat was likely to have been the critical food source in winter, even if a wider variety of foods were consumed in other seasons of the year.

How hominids of the early Pleistocene obtained the bulk of the meat they consumed remains an open question. The technology of the Lower Paleolithic period was comparatively simple, and included no obvious weapons other than wooden spears (e.g., Thieme, 1997). Yet many of the archaeofaunal accumulations dating from 750,000 and 300,000 years ago are dominated by the remains of megafauna such as elephant, mammoth, and woolly rhino. What is more, most of these occurrences are nested within larger, noncultural bone accumulations. Some other early cases seem to indicate successful hunting of medium to large herbivores (i.e., deer, bison, aurochs, horse).

Beginning around 250,000 years ago, and possibly somewhat earlier, there is consistent evidence of large game hunting in the archaeological record. Of course observations about recent human diets show us that large game hunting is only one of several potential dimensions of the human predatory niche. Over the final 250,000 years of the Paleolithic, other trends are evidenced in foraging technology and predatory behavior, especially with respect to small game animals. The temporal focus of this discussion, from 250,000 to 9,000 years ago, encompasses the Middle Paleolithic culture period, associated with Neanderthals and their contemporaries, the Upper Paleolithic, generally but not exclusively the product of anatomically modern Homo sapiens, and the Epi-Paleolithic or Mesolithic. The interval under consideration therefore traverses the biological and cultural transition in which Homo sapiens supplanted earlier forms of the genus Homo. Not without interest, these trends in human economic and social behavior have important demographic correlates. 


\section{Humans as Large Mammal Predators}

The foraging interests of humans overlapped considerably with those of large carnivores during the Pleistocene, particularly in the exploitation of hoofed animals such as deer, wild cattle, horse, and bison. Assuming that the niches of ungulate predators were shaped in part by the risks of interference competition for large resource packages, competition should have fostered differentiation among predator species (Pianka, 1988). Character displacement is evidenced early in the development of the human hunting niche, and hominids' impacts on ungulate prey populations eventually became quite distinct from those of large felids, spotted hyenas, and large canids (Stiner, 1990). Interspecific comparisons reveal that recent humans are the only predator that frequently targets the reproductive core (prime adults) of ungulate populations (Fig. 1). Spotted hyenas and large canids of the recent and

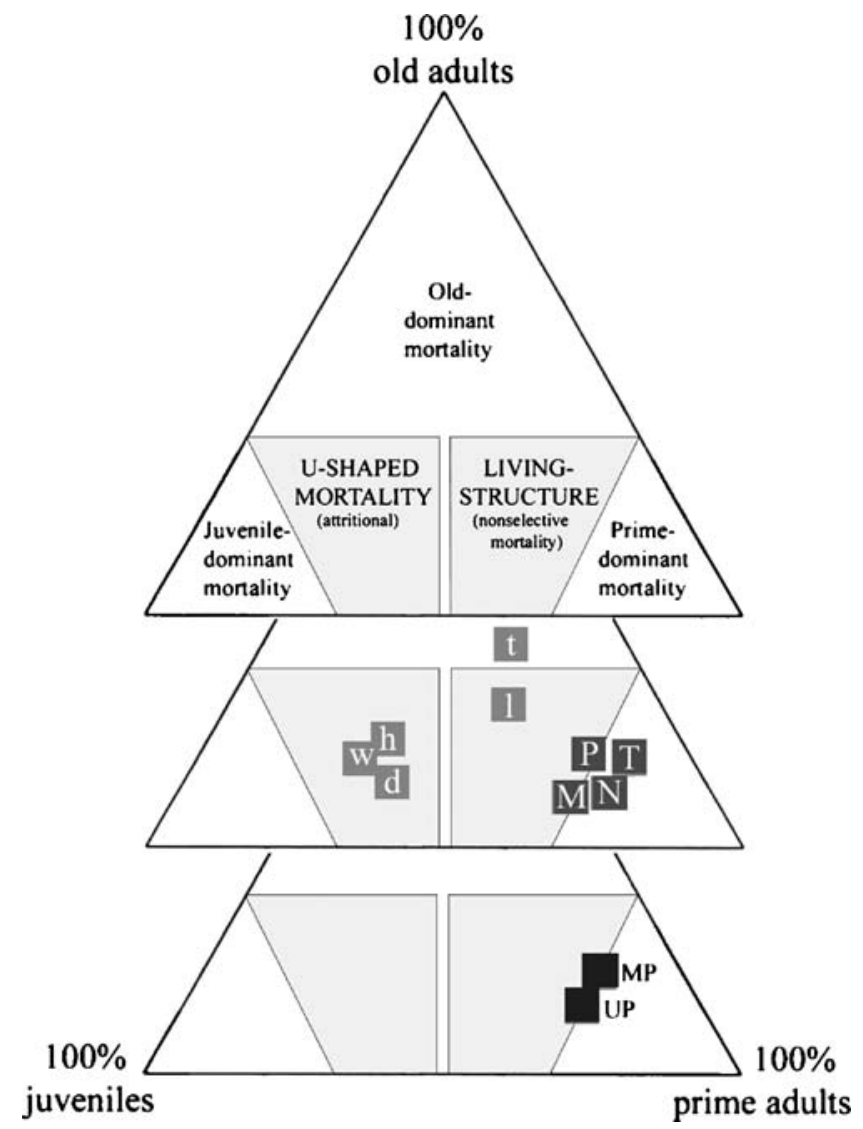

Fig. 1 Comparison of means for ungulate mortality patterns generated by human and nonhuman predators. Shading in right panel represents natural variation in the age structure of living ungulate populations; shaded area in left panel represents mortality patterns caused by attritional factors, such as disease, accidents, and malnutrition. Predators that normally ambush their prey are $[t]$ tigers and $[l]$ lions. Cursorial or long-chase hunters are $[h]$ spotted hyenas, $[w]$ wolves and $[d]$ African wild dogs. Each corner of the graph represents a strong bias toward the designated prey age group. Mean values denoted by open circles are Holocene humans: Paleoindian/Archaic [ $p]$, Mississippian farmers $[m]$, Nunamiut Eskimo $[n]$, trophy hunters in modern game parks $[t]$. MP indicates the mean for most Middle Paleolithic hunted faunas and closely resembles that for the Upper Paleolithic (UP). (From Stiner, 2005.) 
Pleistocene periods generally focus on the juvenile and old adult age groups in the same prey species, and most cats apart from cheetahs tend to take prey more randomly on an encounter basis. From the viewpoint of general predator tendencies, humans' focus on prime adult prey is ecologically unprecedented and is partly complementary to the niches of longer established nonhuman predators.

Current zooarchaeological evidence indicates that prime-adult harvesting of bovids and cervids by Paleolithic humans emerged in the late Middle Pleistocene (Gaudzinski, 1995; Stiner, 2005). It seems likely on theoretical grounds, as well as from limited empirical evidence, that a more basic adaptation for ungulate hunting had evolved in hominids by at least 500,000 years ago. Humans' emphasis on prime-adult prey became geographically ubiquitous after about 100,000 years ago (Stiner, 1990). The general pattern of prime-agebiased hunting appears to have been stable through the Upper Paleolithic culture period, though there may have been a mild reduction in the mean age of animals taken, possibly beginning in the late Middle Paleolithic (Speth and Tchernov, 1998; Stiner, 1994). It was only after the Last Glacial Maximum, and particularly after 13,000 years ago, that human hunting pressure on some ungulate populations led to unsustainable distortions in prey population structures, as indicated by mortality patterns in archaeological sites (Stiner, 2005).

Prime-biased hunting might seem a relatively fragile predator-prey relationship, because it targets adults of reproductive age, including females. Such practices can have negative consequences for the reproductive resilience of prey populations if predators exist at high densities. Even under the latter conditions, however prime-focused hunting may be sustainable for omnivorous predators that can switch to other foods when the population densities of favored prey decline; the more versatile the predators' diet and search images, the more sustainable the relation becomes. In this sense, the human predator-prey relationship described above may not contradict the predictions of "prudent predation" models. It is significant that Middle Paleolithic populations were quite carnivorous based on zooarchaeological evidence, more so perhaps than most human populations of later periods. Studies of stable isotopes from Neanderthal skeletal remains also suggest a diet heavily oriented towards meat (Bocherens and Drucker, 2003; Bocherens et al., 1999; Fizet et al., 1995; Richards et al., 2000, 2001), although such studies currently are too few in number and confined to northern sites where foraging choices would have been narrower as a rule. These observations suggest that Middle Paleolithic foragers (including the Neanderthals) existed at the top of the food chain, implying that Middle Paleolithic populations should have existed at very low densities.

\section{Variation in Prey Body Size, Biomass and Diet Breadth}

Humans are generalists in that they tend to eat a variety of animal and plant foods, and there is much flexibility in dietary breadth among recent foragers. The breadth of forager diets depends upon the availability of high-quality, high-yield foods, among other things (Pianka, 1988; Stephens and Krebs, 1986). Narrow diets, in which low-quality prey are usually ignored, are possible only if the chances of finding more profitable prey types is high. If the encounter rates with preferred prey decline, humans should and generally do broaden their diets by taking more lower-yield types. Dietary diversification is especially likely to occur when and where foragers put excessive pressure on preferred (highly ranked) resources, forcing them into decline. A reduction in the predator population may occur as a result; alternatively, changes in adaptation may occur. 
Early indications of increasing dietary breadth in humans seem to coincide with the transition from the Middle to Upper Paleolithic culture periods in Eurasia. Evidence for this transition is identified in at least three distinct areas of the Mediterranean Basin based mainly on the exploitation of small quick animals, such as birds and lagomorphs, relative to slow-moving collectable small animals such as tortoises and shellfish (Fig. 2). The bulk of meat consumed by all Paleolithic peoples came from large game animals. Small animals were also eaten, but they generally served as back-up resources, apparently essential for adjusting to variation in the availability of large game. The highly conditional nature of small game use in the Paleolithic, along with great differences in the reproductive ecology of the small animals commonly sought, make these data especially revealing about changes in human ecology and demography. The more sensitive of the small prey populationsMediterranean tortoises (Testudo) and certain types of marine shellfish such as limpets (Patella) - represent the proverbial "canaries in the coal mine" for studying shifting human predator-prey interactions of the Pleistocene (Stiner, 2001; Stiner et al., 2000).

The classic models of prey choice and diet breadth assume that resources can be ranked in the energetic terms of the predator, according to the amount of nutritional return they yield relative to the cost of procuring them (Pianka, 1988; Stephens and Krebs, 1986). Broadly speaking, prey rank (sensu relative nutritional payoff) is directly related to some combination of body size and search and handling costs. Ethnographic and experimental evidence suggest that human hunting of large animals provides returns on effort that are several times those from smaller animals, and an order of magnitude larger than many vegetable foods (Kelly, 1995; Kuhn and Stiner, 2001). Holding body size constant, the most important key to Paleolithic rankings of prey in Mediterranean environments has proved to be handling costs. Among the spectrum of small animals taken by Middle and Upper Paleolithic foragers, two important types - tortoises and rock-dwelling marine shellfishcan be placed into a single category of "sessile" game, because they are sluggish or immobile and therefore easily gathered. Quick running or flying animals, such as hares and partridges, have similar body weights to tortoises or several shellfish, but they are far more difficult to collect without the aid of tools, and thus they would be lower ranked in the absence of special capture devices.

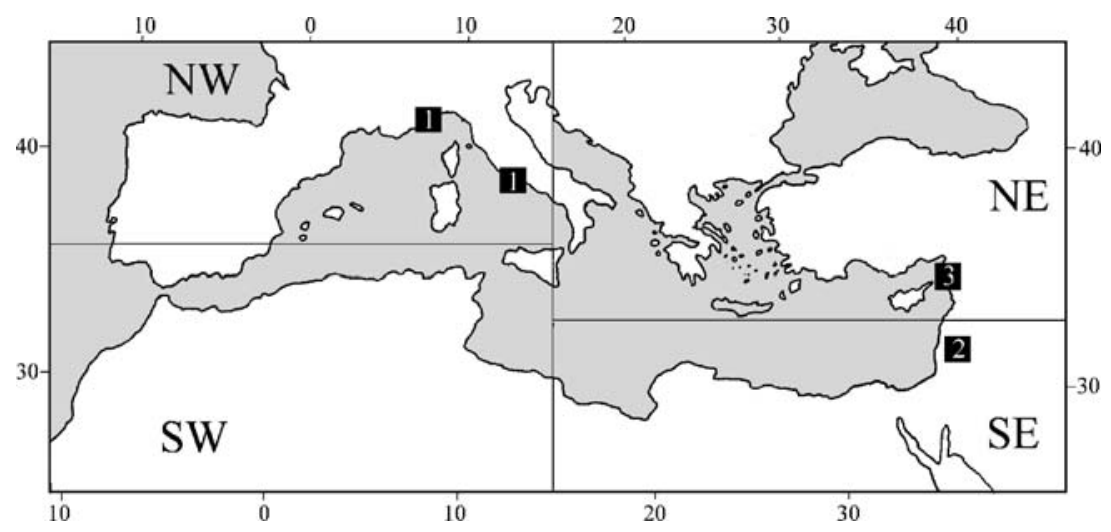

Fig. 2 Geographic origins of the three Mediterranean faunal series: 1 Italy; 2 Israel; 3 Turkey. Four ecological quadrants are distinguished on the basis of endemic species distributions and dominant habitat structures. (Base map after Blondel and Aronson, 1999: 8). 
Simple differences in the ease of capture among the two broad types of Mediterranean small animals happens to correspond to great differences in prey population resilience, the latter governed mainly by the rates at which individual prey animals mature (Stiner et al., 2000). Tortoises and certain types of shellfish (e.g., limpets) are especially susceptible to overharvesting, because they require several years to reach reproductive age. In contrast, rabbits and some ground birds are notorious for their ability to reproduce rapidly and the resilience of their populations.

The relative emphasis that Paleolithic humans placed on small prey types grouped according to predator defense traits - slow-moving or "sessile" animals, fast-running hares and rabbits, and quick flying game birds - shifted dramatically across the eastern and northern Mediterranean Basin within a relatively short time frame (Fig. 3). Zooarchaeological evidence from Italy, Turkey, and Israel indicate that Middle Paleolithic foragers seldom pursued small prey except for those sessile or slow-moving animals (tortoises and shellfish) that could be collected with little effort. The volume of meat biomass obtained from small animals was quite limited (Fig. 4), yet the use of such resources was widespread. The situation changed abruptly around 45-50,000 years ago in the eastern end of the Mediterranean Basin (represented by the long series from Israel), coinciding roughly with the beginning of the Upper Paleolithic culture period and spreading with it into adjacent regions of Eurasia. The proportional contribution in biomass of small game to Paleolithic diets is constant at about 3\% until the late Epi-Paleolithic (after 15,000 years ago), when it rises to $17 \%$ or greater, but the mix of small prey was decidedly broader from the early Upper Paleolithic onward (Munro, 2004; Stiner, 2005).

A closer look at biomass variation in the prey spectrum of Paleolithic hunters (Fig. 4) reveals a progressive decline in ungulate body sizes. This pattern precedes somewhat the rising dependence on small game biomass. Towards the end of the Upper Paleolithic, after the Last Glacial Maximum at roughly 20,000 years ago, biomass of hoofed animals was obtained primarily from medium and small artiodactyl ungulates, and later from small ungulates alone. While the most obvious changes in subsistence ecology occurred after 15,000 years ago, the trend in biomass-to-prey size appears to begin in the early part of the Upper Paleolithic (Fig. 5). Thus we must look to this time range if we are to understand the roots of fundamental changes in human predatory adaptations and socioeconomic patterns.

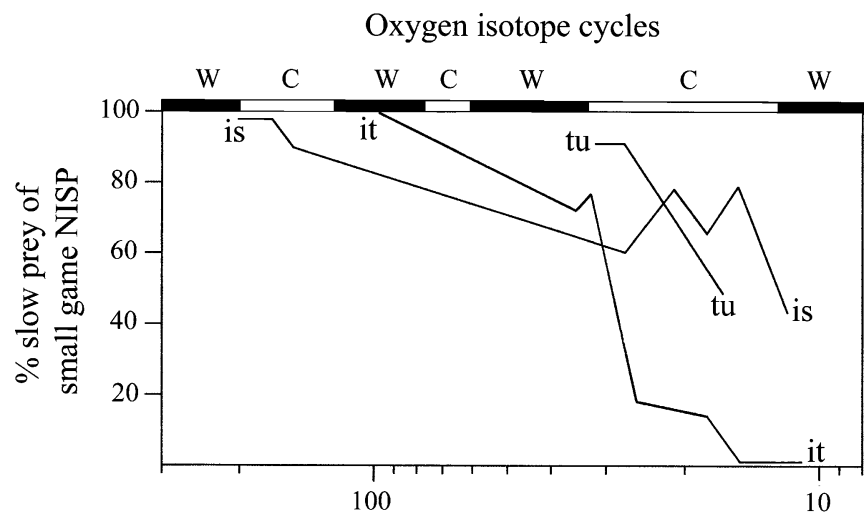

Thousand years before present

Fig. 3 Regional trends (lines) in the percentage of slow prey types within the small game fraction of each assemblage in (is) Israel, (it) Italy, and (tu) Turkey. (From Stiner, 2005.) 
ISRAEL (Galilee)
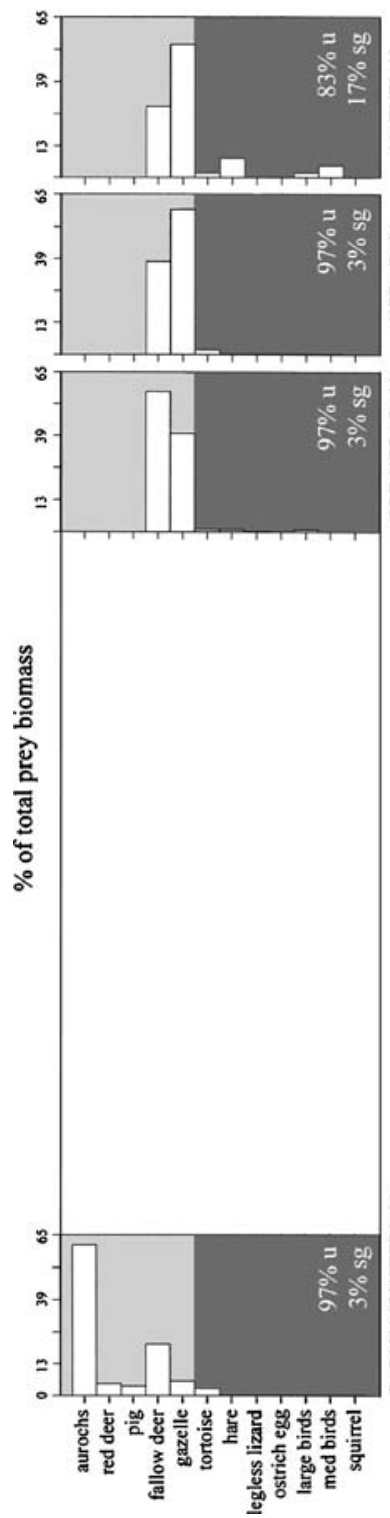

ITALY (Lazio \& Liguria)

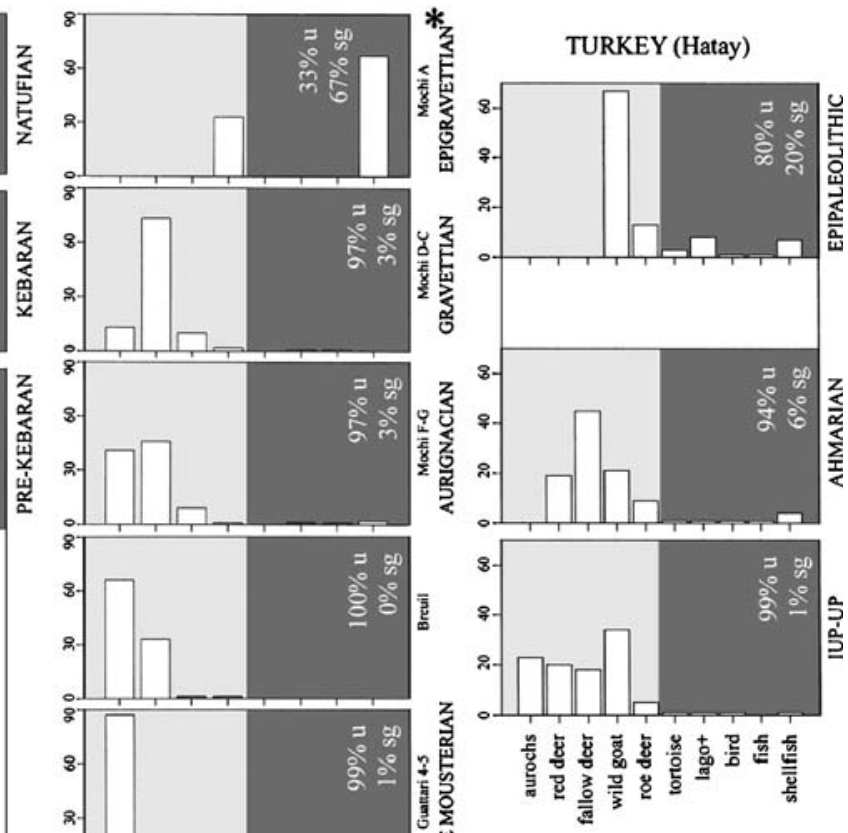

Fig. 4 Percentages of total prey biomass for size-ordered prey species in the three Mediterranean faunal series from Israel, Italy, and Turkey. Only relatively common prey species are considered. (u) Total ungulate percentage, $(\mathrm{sg})$ total small game percentage; $\left(^{*}\right)$ Mochi A in the Italian series represents an extreme situation but is still fairly typical of coastal occupations for the period. Light shading indicates the ungulate (large game) component of the prey spectrum; dark shading refers to the small game component in the same assemblages. (From Stiner, 2005.) 
Fig. 5 Percentage of total prey biomass represented by ungulate prey in the assemblages of each Mediterranean faunal series. (From Stiner, 2005.)

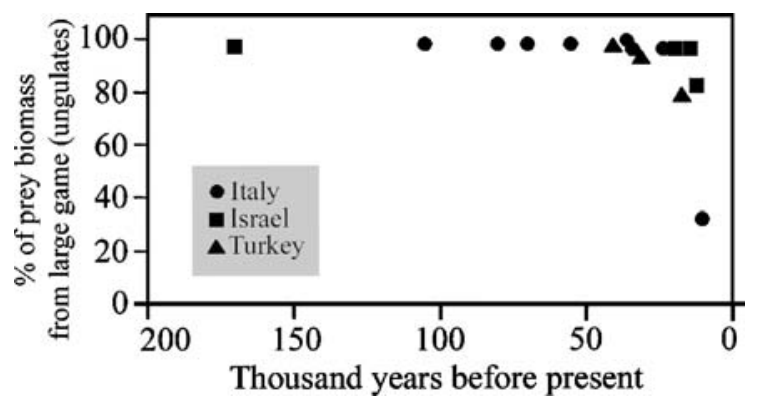

Perhaps the most important observation to be taken from Fig. 4 is that there was greater use with time of faster-reproducing species across the entire prey body size spectrum. While the proportional contribution of small game animals to Paleolithic diets was constant at $3 \%$ until the Epi-Paleolithic, there was a continuous downward shift in prey size overall, and a correspondingly greater emphasis on the more biologically productive ungulate taxa. As discussed below, this phenomenon is also apparent in a different way and earlier within the small game fractions of the Mediterranean faunal series.

An index of "evenness" (the Inverse of Simpson's Index; Simpson, 1949; Levins, 1968) in the small prey types eaten by foragers reveals significant expansion in human dietary breadth coinciding with the onset of the Upper Paleolithic in these areas (Fig. 6). Rather than cycling with climate, the trend spread to the west and north over the next several thousand years. Much of the initial expansion in diet took place during a phase of climate cooling (Oxygen Isotope Stages 3 to 2; following Martinson et al., 1987). Had it occurred only in conjunction with global warming (OIS 3), the trend might not be distinguished easily from natural shifts in animal community diversity and structure (Pianka, 1988). Instead, the evidence points to a categorical change in how humans interacted with small animal populations around the time of the Middle-Upper Paleolithic cultural transition. The

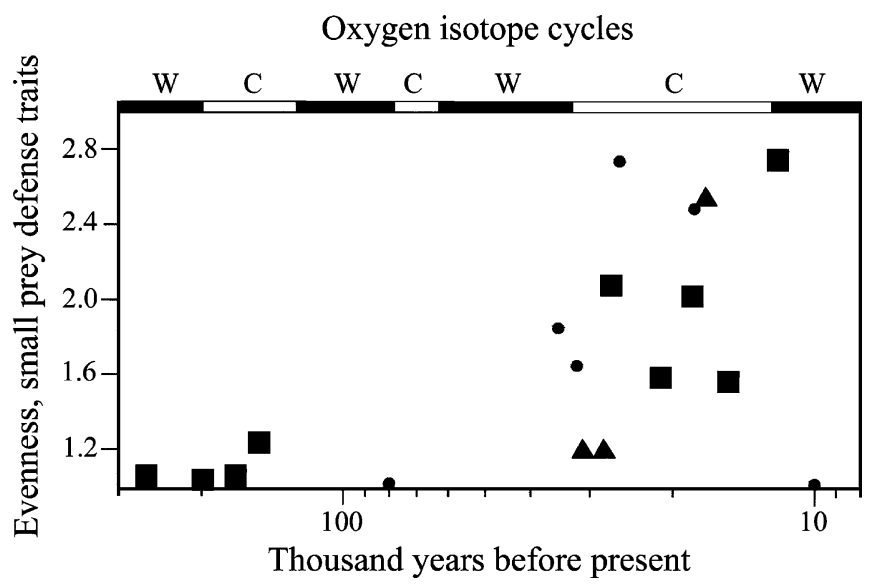

Fig. 6 Comparison of the degree of evenness across three small game categories in Paleolithic faunal assemblages, based on prey defense mechanisms (slow game, quick running terrestrial mammals and quick flying birds) $(3=$ most even, $1=$ least even). Symbols are for assemblages from Italy (circle), Israel (square), and Turkey (triangle). Time is expressed on a logged scale, as are oxygen isotope climate cycles; $(C)$ Cold stage, $(W)$ warm stage. (From Stiner, 2001.) 
burgeoning importance of lagomorphs and other fast moving, fast reproducing small game in human diets is remarkably widespread, extending from the northern interior of Europe to arid lands to the south (Stiner et al., 2000). Environmental changes brought on by global warming (Madeyska, 1999) may have expanded the habitats favored by lagomorphs and thus their numbers in Eurasia. However, paleontological evidence indicates that lagomorphs existed in most or all of these regions in earlier times but were largely ignored by humans (Stiner, 1994; Tchernov, 1994).

Differences in the productivity of prey species are a key to understanding the implications of the economic trends for Paleolithic demography, and rising population densities in particular. An important quality of small prey animals that reproduce quickly is their greater potential reliability as a food source. Warm-blooded small animals, mainly partridges, hares, and rabbits, mature in a year or less, and their populations rebound easily from heavy hunting by humans. Figure 7 summarizes the resilience ranges of the three types of small prey animals common to the Paleolithic series based on predator-prey simulation modeling for high (HGM) and low growth (LGM) conditions (Stiner et al., 2000). The simulations confirm major differences in the scale at which humans could possibly hope to depend on tortoises, hares, and partridge-like birds for meat. Other things being equal, hare populations can support up to seven times greater off-take by predators than tortoises can support, and partridges up to ten times greater off-take than tortoises. This means that humans' reliance on tortoises is only sustainable if human population densities are very low. Human's reliance on partridges and hares is sustainable in both low- and highdensity conditions.

It is striking in light of the simulation results that virtually all Middle Paleolithic foragers in the Mediterranean region focused on slow-growing prey types so consistently, to the extent that they pursued small animals at all. Moreover, where tortoises were an important food source in the Levant, there is no evidence for overharvesting of the tortoises (no diminution or reduction in the mean body size of individuals) until the very end of the Middle Paleolithic (Stiner, 2005; Stiner et al., 1999). Consistent use of slow-growing tortoises during the Middle Paleolithic with no evidence for negative impact on prey populations implies that hominid populations were consistently very small and dispersed. Between 50,000 and 40,000 years ago, however, at the threshold of the Middle-Upper Paleolithic cultural transition, one sees the sudden addition of many fast reproducing but difficult to capture small animals to the diet. This development is accompanied by evidence

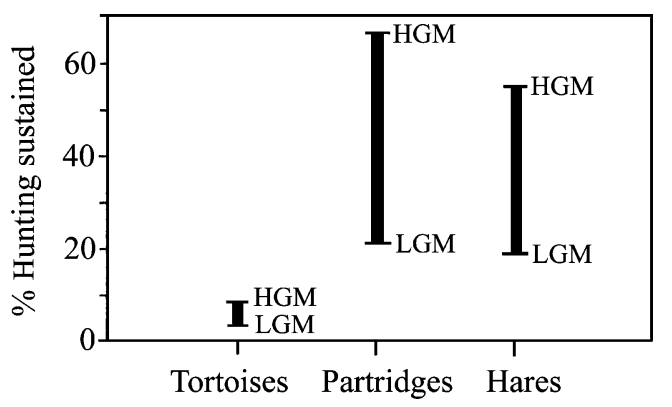

Fig. 7 Comparison of computer-simulated hunting tolerance thresholds for tortoise, partridge, and hare populations under high $(H G M)$ and low $(L G M)$ growth conditions. Upper horizontal bar represents the threshold above which predators' dependence on the designated prey type is no longer sustainable in the HGM: lower horizontal bar represents the LGM threshold. Vertical range for each prey type represents natural variation in population resilience as defined by the LGM and HGM models. (From Stiner et al., 2000.) 
of diminution in sensitive prey populations, implying that human populations began to exceed the availability or potential of high-ranked, high-return resources to support them. The zooarchaeological evidence testifies to further demographic growth in the Mediterranean region over the remainder of the Late Pleistocene, accelerating particularly 15,000 years ago (Bar-Yosef, 1981; Binford, 1968, 1999; Cohen, 1977; Flannery, 1969; Keeley, 1988).

\section{Technological Efficiency and Managed Risk}

The archaeological evidence from Eurasia indicates that some of the major radiations in Paleolithic hunting equipment evolved in response to, or at least postdate, the shifts in hominid subsistence behavior described above. Humans routinely hunted large mammals long before the undisputed or regular appearance of elaborate stone- and bone-tipped weapons in Paleolithic records. Prime-focused ungulate hunting is evidenced by at least 200-250,000 years ago, for example, and the main hunting weapon of the Lower Paleolithic and, apparently, for most of the Middle Paleolithic was the simple wooden spear (Schöningen ca. 400 KYA; Thieme, 1997). In Eurasia Middle Paleolithic hunting weapons sometimes were tipped with pointed stones (Kuhn and Stiner, 2001; Shea, 1989), and some bifacial stone and bone points have been recovered in the later Middle Stone Age of Africa (McBrearty and Brooks, 2000). In contrast, Upper Paleolithic hunting weapons exhibit considerable diversity in design and complexity, and many of them represent significant investments in manufacture. Also contrasting to the Middle Paleolithic is the fact that many of the tool designs of the Upper Paleolithic diversified rapidly in time and space.

Oddly, the elaborate weapons traditions of the Eurasian Upper Paleolithic are separated from the emergence of prime-focused ungulate hunting, an impressive and often dangerous endeavor, by more than 200,000 years. Even the remarkable and apparently precocious examples of weapon tips from Middle Stone Age sites in Africa (d'Errico et al., 2001; McBrearty and Brooks, 2000) are much too young to bridge this temporal gap. It is noteworthy that the designs of Upper Paleolithic foraging technology were very sensitive to environmental variation, quite unlike Lower and Middle Paleolithic technologies. One sees greater abundance of and variation in Upper Paleolithic bone points, for example, in high latitude areas in conjunction with a heavier reliance on hunting. Low-latitude sites contain fewer points but more grinding equipment for processing nuts and seeds, not unlike the global patterns of economic variation among recent hunter-gatherers (Kuhn and Stiner, 2001). In contrast, little variation in hunting technology is apparent within the Middle Paleolithic, even though the sites of this earlier culture period span a geographic range similar to that of Upper Paleolithic humans. The late onset of the technological radiations indicates that the increasing volatility in hunting weapons designs was largely independent of the evolution of human's basic capacity to bring down large prey. Cooperation among hunters, rather than a reliance on elaborate technological aids, must have been essential for the capture of large game animals during the Middle Paleolithic. In fact cooperative hunting tactics are common among social nonhuman predators, such as lions, spotted hyenas, and wolves (e.g., Kruuk, 1972; Schaller, 1972), and such tactics were likely to have been complex in the case of the Neanderthals. It also seems that Middle Paleolithic populations were always sufficiently small and dispersed that their need for meat could be met through a narrow focus on highly ranked game animals.

Many of the changes in weapons design of the later Upper Paleolithic certainly were connected to humans' dietary interest in animals, but the radiations in technology were not 
a gateway to big prey. Improvements in weapons design and efficiency seldom raise the number of large prey animals available to hunters over the long run, as the carrying capacity of environments for herbivorous prey is controlled by a large combination of factors. A heightened investment in weapons efficiency is more likely to reduce individual's procurement time and risk per foray when pursuing large prey or quick small prey, and possibly also the minimum hunting party size needed to capture large animals (Kuhn and Stiner, 2001). This implies a change in the value of forager's time - time that could be allocated to other tasks (Hames, 1992). Thus weapons innovations may have been driven partly by a need for greater mechanical efficiency, but the incentives for doing so may have originated from the pressures of time allocation for diverse social or foraging concerns. Large-scale resource pooling could also have permitted greater individual task specialization, albeit to the extent that human population densities allowed.

Many technological innovations of the Upper Paleolithic seem to relate to the exploitation of small prey, particularly quick-moving aquatic, burrowing, and flying types. Because some of these prey populations rebound quickly, even if hunted heavily, they can be reliable resources to humans if the work of capture can be reduced with new technology (e.g., Oswalt, 1976). Although material evidence is fragmentary, there is good reason to think that trapping and net technologies developed rapidly during the late Upper and EpiPaleolithic or Mesolithic periods (e.g., Adovasio et al., 1996; Gamble, 1986; Gramsch and Kloss, 1989; Jochim, 1998; Mordant and Mordant, 1992; Nadel et al., 1994). The tools for overcoming the quick-flight strategies of birds and small mammals no doubt also permanently altered foragers' systems for ranking prey. The pressure to do so began, however, with predator-prey relationships already under strain. It is interesting, as well, that this happened quite early in the eastern Mediterranean: this region is characterized by high native species diversity and thus provided many opportunities for diversification when and where it became advantageous.

A different side of the technological record concerns innovations in technologies for processing seeds and animal carcasses, which also grew much more complex in the late Upper Paleolithic and especially during the Epi-Paleolithic. Significant increases in carcass processing efficiency included grease rendering via stone boiling, evidenced by the thick litter of fire-cracked stones in some later Upper Paleolithic sites (Audouze, 1987; Stiner, 2003; Svoboda, 1990; Weniger, 1987). Such heat-in-liquid techniques are labor-intensive, but they can raise the protein and fat yields per carcass well beyond what is possible from cold extraction techniques (Binford, 1978; Lupo and Schmitt, 1997). During the Middle Paleolithic and earlier periods, only cold extraction techniques that focused on the concentrated marrow reserves in large medullary cavities were practiced.

To summarize, Fig. 8 outlines some of the more important ecological and cultural developments in hominids from the later part of the Middle Pleistocene to the early Holocene. The earliest niche shift documented within this time span occurred about 500,000 years ago. Though conjectural, this is when fire technology may have first appeared, and hominids became at least seasonally reliant on meat as a result of large-scale colonization of the temperate and colder zones of the Old World. Numbers of sites and hominid fossils in Eurasia also generally increase around this time range to form an unambiguous record of occupation. A second and more certain group of shifts centers on 250,000 years ago and includes the appearance, or perhaps the coalescence, of a distinctly human predator-prey relationship called prime-dominated ungulate hunting. Middle Paleolithic technology, which likely included hide working and tanning, appears around 250,000 years ago. Narrow diets with a heavy dependence on large ungulate game, as well as a lack of impact on sensitive small game resources where they were exploited at all, 


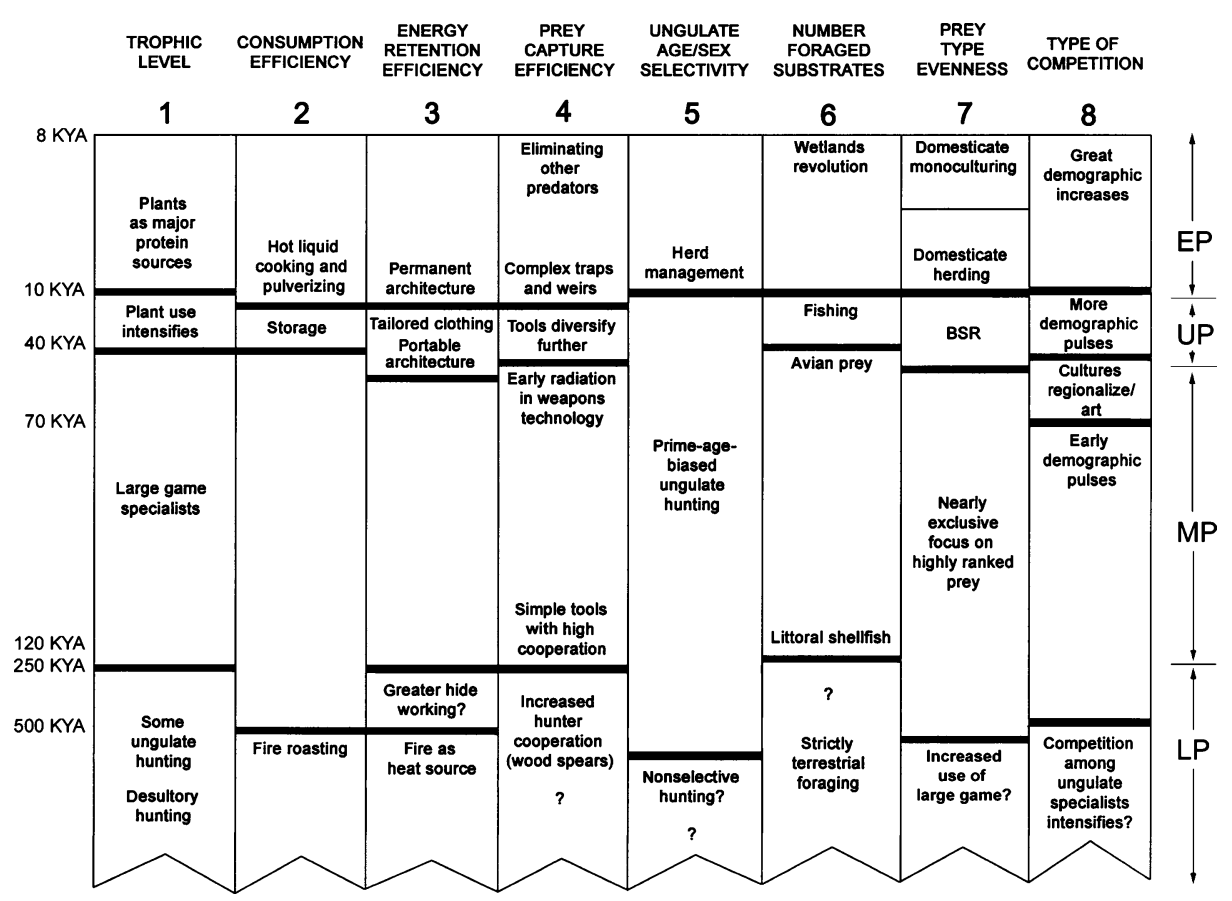

Fig. 8 Threshold shifts in eight niche dimensions of hominids on a logged time scale, lasting 500,000 to 8,000 years ago. Niche dimensions generally follow those outlined by Pianka (1988). Annotations refer to particular behavioral and trophic developments associated with each transition. ( $k y)$ Thousand years before present, $(m y)$ million years before present, $(E P)$ epipaleolithic period, $(U P)$ Upper Paleolithic, $(M P)$ Middle Paleolithic, (LP) Lower Paleolithic. (From Stiner, 2005.)

indicate that hominid population densities stayed very low throughout the Middle Paleolithic; evidence from site numbers per unit time corroborates this (Mirazón Lahr and Foley, 2003; van Andel et al., 2003). Human behavioral adaptations of this period display great stability, persisting for 200,000 years or more with only minor behavioral variations across a wide range of environments.

Upper Paleolithic cultures first appeared between 50,000 and 45,000 years ago in the eastern Mediterranean area, and they replaced all Middle Paleolithic adaptations in Eurasia by roughly 30,000 years ago. Early demographic pulses clearly accompany this cultural transition, and expanding Upper Paleolithic populations must have squeezed some Middle Paleolithic populations in the areas of contact. From the Upper Paleolithic, the pace of change in material culture accelerated on multiple fronts, along with the novel additions of body ornaments, decorated tools, and art (there is virtually no evidence of art in the Middle Paleolithic). The final series of shifts seems to grow out of extreme climate oscillations, beginning with the Last Glacial Maximum, 20,000 years ago, and followed by rapid global warming. After 50,0000 years ago, the rates of change in the eight niche dimensions listed above seem to accelerate. The shifts in energy retention and consumption efficiency, and the rising importance of intraspecific competition, are almost certainly linked to demographic increase. Just how this process unfolded remains to be understood, as the evidence presented so far only identifies temporal and geographic relations between demographic pulses and socioeconomic change, not its causes. 
Certain correlates in material culture may provide clues as to what allowed this demographic upsurge. The sudden appearance of a myriad of ornaments and other decorated objects in early Upper Paleolithic culture (d'Errico et al., 1998; Kuhn et al., 2001; Stiner, 1999; White, 1993) may testify to a need to broadcast aspects of identity or links in the context of enlarged social networks. Among recent hunter-gatherers, such artifacts also play roles in gifting and alliance networking (Wiessner, 1983), a means for formalizing the intention of delayed reciprocation. Human demographic increase of the Upper Paleolithic may have created feedback situations in which human social networks could be exploited more efficiently in order to spread foraging risk over larger areas.

The increasing regionalization of artifact styles that characterizes the late Pleistocene and early Holocene in Eurasia (the later Upper Paleolithic, Epi-Paleolithic and Mesolithic periods; e.g., Newell et al., 1990; Price, 1991), suggest that the challenges to human survival came from the lay of cultural landscapes as much as from natural ones. While sharing and cooperative foraging must have been a part of Middle Paleolithic lifeways, the social worlds of Middle Paleolithic hominids would have been quite small by comparison (Gamble, 1999). The demographic conditions that make large, open-ended networks numerically possible seem to postdate the Middle Paleolithic and may have contributed to its demise. Whatever the causes of demographic increase, in the Upper Paleolithic the conditions of selection on human societies and foraging behavior shifted to a more profoundly intraspecific forum. The resilience of Upper Paleolithic populations may have stemmed in large part from niche differentiation within the human species, specialization in activities and labor allocation between the sexes and probably also by age. This is the cooperative division of labor that became characteristic of all recent human societies (Kuhn and Stiner, 2006).

\section{Cultural Conservatism vs. Volatility}

The archaeological signatures of the Middle Paleolithic are remarkably consistent across time and space. This apparent uniformity in behavior has been taken by some investigators to indicate significant cognitive limitations of Middle Paleolithic foragers (Klein, 1999). However, the ecological data on early humans presented here suggest that the "inflexibility" we see in Middle Paleolithic culture was a product of the success and stability of the adaptation, and not necessarily a question of intelligence. Estimates of the rates of longterm demographic increase before 50,000 years ago are remarkably low (Pennington, 2001), a conclusion that also is supported by the zooarchaeological data. There seems to have been a lack of pressure or economic incentive for large-brained, mobile Middle Paleolithic hunters to squeeze more out of traditional food supplies, little if any long-term selection for greater foraging efficiency. This implies that, like other organisms but unlike recent humans, Middle Paleolithic hominids responded to long-term fluctuations in environmental productivity and population-resource imbalances almost exclusively through localized depopulation, rather than by intensifying resource extraction or diet diversification. In fact, the demography of Middle Paleolithic foragers was consistent with the population dynamics and low densities of a variety of formidable nonhuman predators.

Far more difficult to explain than Middle Paleolithic conservatism is the downward shift in trophic level that is so characteristic of many later human subsistence systems. One of the most arresting features of the Upper Paleolithic is the near "irreversibility" of the dietary trends - persistent diversification via the inclusion of lower-ranked foodstuffs (plant and animal) that have greater collecting costs, processing costs, or both. The shift in predatory 
economics would have resulted in increases in environmental carrying capacity for Upper Paleolithic populations.

How could higher population densities become a permanent condition for humans in the late Pleistocene? Humans have developed an astonishing variety of tactics for insulating social groups from the unpredictable nature of their food supplies. Among these, smallscale storage of consolidated animal tissues, seeds and nuts, or both may have been pivotal in the later Upper Paleolithic. Storage buffers human groups against fluctuations in annual resource abundance, especially in situations where residential mobility, exchange or sharing cannot solve the problem (Soffer, 1989). More efficient carcass processing methods may increase the yield of any given food unit, but the greater amount of work required to extract it normally must be weighed against the prospects of getting more food. Innovations in technology are apparent for most of these behaviors. Human technology today does indeed facilitate overharvesting of food species. However, calling this ability simply the product of invention or 'inventiveness,' or an isolated accident of history, is insufficient to explain the evolutionary processes that have allowed humans to exert ever greater impacts on native biota.

Under conditions of population pressure, a shift toward greater dependence on more biologically "productive" or resilient prey populations may also have presented fundamental short-term advantages, even if it meant a heavier technological investment to overcome handling costs. A reduction in the variance in the costs of acquisition can lead to a more consistent supply of animal protein and fats and significantly improve child survivorship without an increased birth rate. Meat is one of the very few sources of complete protein in nature, a fact that no doubt sharpens humans' interest in obtaining it in large packages. The human body cannot store undedicated protein as it does the nutrients that yield food energy, nor can the body assimilate protein effectively in the absence of energy supplements (Speth and Spielmann, 1983). Daily requirements for complete dietary protein are modest but constant, especially for children and mothers. Ethnographic research (Hawkes et al., 1997; Yellen, 1991) suggests that the most consistent sources of protein, and in some cases fat, for hunter-gatherer children in arid environments are the small animals and certain nuts that children either procure for themselves or are provided by female kin. The opportunities to obtain small animals are also considerably more diverse and widespread than are the opportunities to obtain large game, as are the personnel who may pursue them. As a result, increasing use and diversified exploitation of small game animals implies changes in the division of labor in foraging societies.

The trends in small game use along the Mediterranean Rim may inadvertently have stabilized humans' access to protein as the abundance of highly ranked but relatively unproductive prey declined (for a related argument, see Winterhalder and Goland, 1993). The addition of these novel resources to Paleolithic diets may have also allowed a wider range of individuals in human groups to become productive foragers, increasing or eveningout protein and energy intake for the group as a whole. Specifically, the development of capture devices such as snares, deadfalls, and nets may have afforded more reliable access to small protein packages from formerly elusive but perennially abundant small animals.

Of course the price of dietary diversification was higher investment in tool preparation and maintenance as well as direct inputs of labor to capture small animals in quantity. It is doubtful that all evolution in tool design can be explained by superior mechanical performance and efficiency (Kuhn and Stiner, 1998), but it is clear that some of the changes were spurred by the dwindling supplies of high quality resources. In western Asia, we note that human demographic pressure preceded rather than followed the earliest technologic innovations of the Upper and Epi-Paleolithic periods. 


\section{Connectedness and Resilience in Paleolithic Systems}

The units of behavior that archaeologists study are contained within very broadly defined cultural entities, and it must be admitted that these entities probably are not coterminous with biological populations. Moreover, statements about sustained demographic presence or growth in the past require much clarity about the scale at which systems are conceived, something we have attempted to do here within the limits of the archaeological data. From this information, we can distinguish some properties of Middle Paleolithic as opposed to Upper Paleolithic and all later cultural adaptations. An essential property of Upper Paleolithic culture appears to have been its ability to reinvent itself, whereas Middle Paleolithic culture seems to have persisted by virtue of widespread cultural conservatism.

Does this mean that Upper Paleolithic culture and people were superior to or smarter than Middle Paleolithic types? This kind of assertion is widespread in the professional and lay literature on the demise of Neanderthals. It is, however, a bit like arguing that college professors are unintelligent, because they tend to have fewer children than other segments of postindustrial human populations. We know that the adaptive systems of the Middle and Lower Paleolithic were very persistent in time and space and must have represented successful adaptations for long periods. Yet these human reproductive units probably were not particularly robust at the micropopulation scale. The rather narrow set of behavioral responses that characterized social groups prior to the Upper Paleolithic period almost guarantees that localized extinctions at the micropopulation level would have been common. Upper Paleolithic groups were the quintessential colonizers and, in addition, exceptionally good at holding on to habitat gained - these populations expanded rapidly through Eurasia, apparently originating from subtropical and warm-temperate areas at or greater than 45,000 years ago, and quietly snuffing out the last Neanderthals by roughly 30,000 years ago regardless of whether admixture occurred.

The demographic robustness of the Upper Paleolithic systems, which permitted their rapid expansion into vast new areas, may have been a by-product of new strategies for evening-out or sharing risk and the exceptional volatility of their technologies. Micropopulations of the Upper and Epi-Paleolithic were more connected geographically, at least based on stylistic evidence (Gamble, 1986, 1999), and thus more robust. Larger networks for spreading risk may have set some Upper Paleolithic populations at advantage, allowing them to grow somewhat faster or at least to experience fewer oscillations in population size, disadvantaging Middle Paleolithic populations wherever they came in contact (Kuhn and Stiner, 2006).

The apparent contrast in the flexibility of human adaptations between the Middle and Upper Paleolithic culture periods is bound to raise some interesting challenges to theoretical concepts of "robustness" or "resilience" in research on evolutionary dynamics. At issue from a paleoanthropological viewpoint is the question of how systems are to be defined, and how one may distinguish adjustments within the bounds of an extant system from evolutionary changes that bring new a system into existence. If the system of interest springs back from perturbations in a slightly altered form, for example, shall we call it a new system, or is this evidence for robustness of the preexisting system? It is striking that the adaptive system(s) of the Upper Paleolithic, to the extent that these are coterminous with archaeological "cultures," have shorter histories of existence than those of the Neanderthals and earlier hominids, yet Upper Paleolithic populations were even more widespread geographically and existed at higher densities in many areas (Foley and Lahr, 1997). Upper Paleolithic and later cultural systems appear to have reorganized frequently in the service of demographic robustness - resulting from feedback relations with subsistence 
diversification in diet, technical intensification, and social strategies for spreading risk. Earlier hominid population-level systems look fragile by comparison, even though their cultural traditions appear to have been extraordinarily stable for long periods. Middle Paleolithic and earlier hominid populations of Eurasia were smaller, more scattered, and for this reason more subject to the unique historical predicaments of annual and interannual variation in food supplies and habitat conditions.

Demographic factors are an important background to understanding evidence for changes in the connectedness of social entities within cultures and their relations to environmental systems in the evolutionary history of humans. For a very long time hominids were energetically of little significance in the ecosystems in which they lived. The effects of fluctuating environments on hominid populations are detectable over millions of years, but evidence of influences in the reverse direction is much more recent. Distinctly human impacts on community structure and prey populations first become detectible only after about 50-40,000 years ago, with the onset of the Upper Paleolithic. These later humans often responded socially and technologically rather than simply demographically to periodic scarcity of resources. The ecological and demographic crises that seem so unique to the modern world have deep roots in the history of forager adaptations.

Acknowledgments We first presented this paper in a special symposium in May, 2003, entitled "Coupled Human and Natural Systems," hosted jointly by the National Science Foundation Program (BCS-BE: Dynamics of Coupled Natural-Human Systems, \#0215989) and the Santa Fe Institute. The symposium was a collaborative effort on the part of Erica Jen, Lisa M. Curran, J. Stephen Lansing, Thomas K. Park, and the first author. We are grateful to the Santa Fe Institute for hosting the conference and providing a forum for the fertile intellectual exchanges that have followed. We also thank anonymous Human Ecology reviewers for their comments on the penultimate version of the manuscript.

\section{References}

Adovasio, J. M., Soffer, O., and Klima, B. (1996). Paleolithic fiber technology: data from Pavlov I, ca. 26,000 B.P. Antiquity 70: 526-534.

Audouze, F. (1987). The paris basin in Magdalenian times. In Soffer, O. (ed.), The Pleistocene Old World: Regional Perspectives, Plenum, New York, pp. 183-200.

Barton, R. N. E., Currant, A. P., Fernandez-Jalvo, Y., Finlayson, J. C., Goldberg, P., Macphail, R., Pettitt, P. B., and Stringer, C. B. (1999). Gilbraltar Neanderthals and results of recent excavations in Gorham's, Vanguard and ibex caves. Antiquity 73: 13-23.

Bar-Yosef, O. (1981). The Epi-Palaeolithic complexes in the southern Levant. In Cauvin, J., and Sanlaville, P. (eds.), Prehistoire du Levant, Éditions du C.N.R.S., Paris, pp. 389-408.

Binford, L. R. (1968). Post-Pleistocene adaptations. In Binford, S. R., and Binford, L. R. (eds.) New Perspectives in Archaeology, Aldine, Chicago, pp. 313-341.

Binford, L. R. (1978). Nunamiut Ethnoarchaeology. Academic, New York.

Binford, L. R. (1999). Time as a clue to cause? Proceedings of the British Academy 101: 1-35.

Binford, L. R., and Ho, C. K. (1985). Taphonomy at a Distance: Zhoukoudian, "the cave home of Beijing Man?" Current Anthropology 26: 413-442.

Blondel, J., and Aronson, J. (1999). Biology and Wildlife of the Mediterranean Region, Oxford University Press, Oxford and New York.

Bocherens, H., and Drucker, D. E. (2003). Reconstructing Neandertal diet from 120,000 to 30,000 BP using carbon and nitrogen stable isotopic abundances. In Patou-Mathis, M., and Bocherens, H. (eds.), Le Rôle de l'Envireonnement dans le Comportements des Chasseurs-Cuillieurs Préhistoriques. BAR International Series 1105, British Archaeological Reports, Oxford, pp. 1-8.

Bocherens, H., Billiou, D., Marotti, A., Patou-Mathis, M., Otte, M., Bonjean, D., and Toussaint, M. (1999). Palaeoenvironmental and palaeodietary implications of isotopic biogeochemistry of last interglacial neanderthal and mammal bones in scladina cave (Belgium). Journal of Archaeological Science 26: 599-607. 
Cohen, M. N. (1977). The Food Crisis in Prehistory: Overpopulation and the Origins of Agriculture, Yale University Press, New Haven.

Dennell, R. W., and Roebroeks, W. (1996). The earliest colonization of Europe: the short chronology revisited. Antiquity 70: 535-542.

d'Errico, F., Zilháo, J., Julien, M., Baffier, D., and Pelegrin, J. (1998). Neanderthal acculturation in Western Europe? A critical review of the evidence and its interpretation. Current Anthropology 39(Supplement): $1-44$.

d'Errico, F., Henshilwood, C., and Nilssen, P. (2001). Engraved bone fragment from c. 70,000-year-old Middle Stone Age Levels at Blombos Cave, South Africa: implications for the origin of symbolism and language. Antiquity 75: 309-318.

Fizet, M., Mariotti, A., Bocherens, H., Lange-Badré, B., Vandermeersch, B., Borel, J., and Bellon, G. (1995). Effect of diet, physiology and climate on carbon and nitrogen stable isotopes of collagen in a late pleistocene anthropic paleoecosytem (France, Charente, Marillac). Journal of Archaeological Science 22: $67-79$.

Flannery, K. V. (1969). Origins and ecological effects of early domestication in Iran and the Near East. In Ucko, P. J., and Dimbleby, G. W. (eds.), The Domestication and Exploitation of Plants and Animals, Aldine, Chicago, pp. 73-100.

Foley, R., and Lahr, M. M. (1997). Mode 3 technologies and the evolution of modern humans. Cambridge Archaeological Journal 7(1): 3-36.

Gabunia, L., Vekua, A., Lordkipanidze, D., Swisher, C. C. III, Ferring, R., Justus, A., Nioradze, M., Tvalchrelidze, M., Antón, S. C., Bosinski, G., Jöris, O., de Lumley, M.-A., Majsuradze, G., and Mouskhelishvili, A. (2000). Earliest pleistocene hominid cranial remains from Dmanisi, Republic of Georgia: taxonomy, geological setting, and age. Science 288: 1019-1025.

Gamble, C. (1986). The Palaeolithic Settlement of Europe, Cambridge University Press, Cambridge.

Gamble, C. (1999). Palaeolithic Societies of Europe, Cambridge University Press, Cambridge.

Gaudzinski, S. (1995). Wallertheim revisited: a re-analysis of the fauna from the Middle Palaeolithic site of Wallertheim (Rheinhessen/Germany). Journal of Archaeological Science 22: 51-66.

Gibert, J. (ed.) (1992). Proyecto Orce-Cueva Victoria (1988-1992): Presencia Humana en el Pleistoceno interior de Granada y Murcia, Ayuntamiento de Orce (Granada), Museo de Prehistoria "J. Gibert," Granada.

Goren-Inbar, N. (1992). The Acheulian site of Gesher Benot Ya'aqov: an African or Asian entity? In Akazawa, T., Aoki, K., and Kimura, T. (eds.), The Evolution and Dispersal of Modern Humans in Asia, Hokusen-Sha, Tokyo, pp. 67-82.

Gramsch, B., and Kloss, K. (1989). Excavations near Friesack: an early Mesolithic marshland site on the northern plain of Central Europe. In Bonsall, C. (ed.), The Mesolithic in Europe, John Donald, Edinburgh, pp. 313-324.

Hames, R. (1992). Time allocation. In Smith, E. A., and Winterhalder, B. (eds.), Evolutionary Ecology and Human Behavior, Aldine de Gruyter, New York, pp. 203-235.

Hawkes, K., O'Connell, J. F., and Blurton Jones, N. (1997). Hadza women's time allocation, offspring provisioning, and the evolution of long postmenopausal life spans. Current Anthropology 38(4): 551-577.

Jochim, M. (1998). A Hunter-gatherer Landscape: Southwest Germany in the Late Paleolithic and Mesolithic, Plenum, New York.

Keeley, L. H. (1988). Hunter-gatherer economic complexity and "population pressure." Journal of Anthropological Archaeology 7: 373-411.

Kelly, R. (1995). The Foraging Spectrum: Diversity in Hunter-Gatherer Lifeways, Smithsonian Institution, Washington, District of Columbia.

Klein, R. G. (1999). The Human Career: Human Biological and Cultural Origins, University of Chicago, Chicago and London.

Kretzoi, M., and Dobosi, V. T. (1990). Vertesszolos: Site, Man and Culture, Adademiai Kiado, Budapest.

Kruuk, H. (1972). The Spotted Hyaena, University of Chicago, Chicago.

Kuhn, S. L., and Stiner, M. C. (1998). Middle Paleolithic 'creativity': reflections on an oxymoron? In Mithen, S. (ed.), Creativity and Human Evolution and Prehistory, Routledge, London and New York, pp. $143-164$.

Kuhn, S. L., and Stiner, M. C. (2001). The antiquity of hunter-gatherers. In Panter-Brick, C., Layton, R. H., and Rowley-Conwy, P. A. (eds.), Hunter-gatherers: Interdisciplinary Perspectives, Cambridge University Press, Cambridge, pp. 99-142.

Kuhn, S. L., and Stiner, M. C. (2006). What's a mother to do? A hypothesis about the division of labor and modern human origins. Current Anthropology 47(6): December issue.

Kuhn, S. L., Stiner, M. C., Reese, D. S., and Güleç, E. (2001). Ornaments in the earliest upper paleolithic: new results from the levant. Proceedings of the National Academy of Sciences 98(13): 7641-7646. 
Levins, R. (1968). Evolution in Changing Environments: Some Theoretical Explorations, Princeton University Press, Princeton.

Lupo, K. D., and Schmitt, D. N. (1997). Experiments in bone boiling: nutritional returns and archaeological reflections. Anthropozoologica 25-26: 137-144.

Madeyska, T. (1999). Palaeogeography of European lowland during the late Vistulian. In Kobusiewicz, M., and Kozlowski, J. K. (eds.), Post-pleniglacial Re-colonization of the Great European Lowland, Folia Quaternaria 70, Polska Akademia Umiejêtnoœci, Komisja Paleogeografii Czwartorzêdu, Kraków, pp. 7-30.

Mallegni, F. (1992). Il più antico popolamento umano. In Guidi, A., and Piperno, M. (eds.), Italia Preistorica, Editori Laterza, Roma, pp. 103-138.

Martinson, D. G., Pisias, N. G., Hays, J. D., Imbrie, J., Moore, T. C., and Shackleton, N. J. (1987). Age dating and the orbital theory of the ice ages: development of a high-resolution 0 to 300,000 -year chronostratigraphy. Quaternary Research 27: 1-29.

McBrearty, S., and Brooks, A. (2000). The revolution that wasn't: a new interpretation of the origin of modern human behavior. Journal of Human Evolution 39: 456-463.

Mirazón Lahr, M., and Foley, R. (2003). Demography, dispersal and human evolution in the Last Glacial period. In van Andel, T. H., and Davies, W. (eds.), Neanderthals and Modern Humans in the European Landscape during the Last Glaciation, McDonald Institute for Archaeological Research, University of Cambridge, Cambridge, pp. 241-256.

Mordant, C., and Mordant, D. (1992). Noyen-sur-Seine: A Mesolithic waterside settlement. In Coles, B. (ed.), The Wetland Revolution in Prehistory, The Prehistoric Society, Exeter, pp. 55-64.

Munro, N. D. (2004). Zooarchaeological measures of human hunting pressure and site occupation intensity in the natufian of the Southern Levant and the implications for agricultural origins. Current Anthropology 45(Supplement): 5-33.

Nadel, D., Danin, A., Werker, E., Schick, T., Kislev, M. E., and Stewart, K. (1994). 19,000-year-old twisted fibers from ohalo I. Current Anthropology 35(4): 451-458.

Newell, R. R., Kielman, D., Constandse-Westermann, T. S., van der Sanden, W. A. B., and van Gijn, A. (1990). An Inquiry into the Ethnic Resolution of Mesolithic Regional Groups: The Study of Their Decorative Ornaments in Time and Space, E. J. Brill, Leiden, Netherlands.

Oswalt, W. H. (1976). An Anthropological Analysis of Food-Getting Technology, Wiley, New York.

Pennington, R. (2001). Hunter-gatherer demography. In Panter-Brick, C., Layton, R. H., and Rowley-Conwy, P. A. (eds.), Hunter-gatherers: Interdisciplinary Perspectives, Cambridge University Press, Cambridge, pp. 170-204.

Pianka, E. R. (1988). Evolutionary Ecology, 4th ed. Harper and Row, New York.

Price, T. D. (1991). The Mesolithic of Northern Europe. Annual Review of Anthropology 20: 211-233.

Richards, M., Pettitt, P., Trinkaus, E., Smith, F., Paunović, M., and Karavanić, I. (2000). Neanderthal diet at Vindija and Neanderthal predation: the evidence from stable isotopes. Proceedings of the National Academy of Sciences 97(13): 7663-7666.

Richards, M., Pettitt, P. B., Stiner, M. C., and Trinkaus, E. (2001). Stable isotope evidence for increasing dietary breadth in the European Mid-Upper Paleolithic. Proceedings of the National Academy of Sciences 98(11): 6528-6532.

Roebroeks, W. (2005). Life on the Costa del Cromer. Nature 438(15): 921-922.

Roebroeks, W., Conard, N. J., and van Kolfschoten, T. (1992). Dense forests, cold steppes, and the palaeolithic settlement of Northern Europe. Current Anthropology 33(5): 551-586.

Rolland, N. (1998). The Lower Palaeolithic settlement of Eurasia, with special reference to Europe. In Petraglia, M. D., and Korisettar, R. (eds.), Early Human Behaviour in Global Context: The Rise and Diversity of the Lower Palaeolithic Record, Routledge, London, pp. 187-220.

Sémah, F., Saleki, H., and Falguères, C. (2000). Did early man reach java during the Late Pliocene? Journal of Archaeological Science 27: 763-769.

Schaller, G. B. (1972). The Serengeti Lion, University of Chicago, Chicago.

Shea, J. (1989). A functional study of the lithic industries associated with hominid fossils in the Kebara and Qafzeh caves, Israel. In Mellars, P., and Stringer, C. (eds.), The Human Revolution, Princeton University Press, Princeton, pp. 611-625.

Simpson, E. H. (1949). Measurement of diversity. Nature 163: 688.

Soffer, O. (1989). The Middle to Upper Palaeolithic transition on the Russian Plain. In Mellars, P., and Stringer, C. (eds.), The Human Revolution, Princeton University Press, Princeton, pp. 714-742.

Speth, J. D., and Spielmann, K. A. (1983). Energy source, protein metabolism, and hunter-gatherer subsistence strategies. Journal of Anthropological Archaeology 2: 1-31.

Speth, J. D., and Tchernov, E. (1998). The role of hunting and scavenging in Neanderthal procurement strategies: new evidence from Kebara Cave (Israel). In Akazawa, T., Aoki, K., and Bar-Yosef, O. (eds.), Neanderthals and Modern Humans in West Asia, Plenum, New York, pp. 223-239. 
Stekelis, M. (1966). The Lower Pleistocene of the Central Jordan Valley: Archaeological Excavations at 'Ubeidiya, 1960-1963, The Israel Academy of Sciences and Humanities, Jerusalem.

Stephens, D. W., and Krebs, J. R. (1986). Foraging Theory, Princeton University Press, Princeton.

Stiner, M. C. (1990). The use of mortality patterns in archaeological studies of hominid predatory adaptations. Journal of Anthropological Archaeology 9: 305-351.

Stiner, M. C. (1994). Honor Among Thieves: A Zooarchaeological Study of Neandertal Ecology, Princeton Univeristy Press, Princeton.

Stiner, M. C. (1999). Trends in Paleolithic mollusk exploitation at Riparo Mochi (Balzi Rossi, Italy): food and ornaments from the Aurignacian through Epigravettian. Antiquity 73(282): 735-754.

Stiner, M. C. (2001). Thirty years on the "Broad Spectrum Revolution" and Paleolithic demography. Proceedings of the National Academy of Sciences 98(13): 6993-6996.

Stiner, M. C. (2003). Zooarchaeological evidence for resource intensification in Algarve, Southern Portugal. Promontoria 1: 27-61.

Stiner, M. C. (2005). The Faunas of Hayonim Cave (Israel): A 200,000-Year Record of Paleolithic Diet, Demography and Society, American School of Prehistoric Research, Bulletin 48, Peabody Museum, Harvard University, Cambridge.

Stiner, M. C., Munro, N. D., Surovell, T. A., Tchernov, E., and Bar-Yosef, O. (1999). Paleolithic population growth pulses evidenced by small animal exploitation. Science 283: 190-194.

Stiner, M. C., Munro, N. D., and Surovell, T. A. (2000). The tortoise and the hare: Small game use, the Broad Spectrum Revolution, and Paleolithic demography. Current Anthropology 41(1): 39-73.

Svoboda, J. (1990). Moravia during the Upper Pleniglacial. In Gamble, C., and Soffer, O. (eds.), The World at 18,000 BP, Volume 2: Low Latitudes, Plenum, New York, pp. 193-203.

Swisher, C. C., Curtis, G. H., Jacob, T., Getty, A. G., and Suprijo Widiasmoro, A. (1994). Age of the earliest known hominids in Java, Indonesia. Science 263: 1118-1121.

Tchernov, E. (1981). The biostratigraphy of the Middle East. In Cauvin, J., and Sanlaville, P. (eds.), Prehistoire du Levant, Éditions du C.N.R.S., Paris, pp. 67-97.

Tchernov, E. (1992a). Eurasian-African biotic exchanges through the Levantine corridor during the Neogene and Quaternary. Courier Forschungsinstitut Senckenberg 153: 103-123.

Tchernov, E. (1992b). Evolution of complexities, exploitatation of the biosphere and zooarchaeology. Archaeozoologica V(1): 9-42.

Tchernov, E. (1994). New comments on the biostratigraphy of the Middle and Upper Pleistocene of the southern Levant. In Bar-Yosef, O., and Kra, R. S. (eds.), Late Quaternary Chronology and Paleoclimates of the Eastern Mediterranean, RADIOCARBON, University of Arizona, Tucson, pp. 333-350.

Thieme, H. (1997). Lower Palaeolithic hunting spears from Germany. Nature 385: 807-810.

van Andel, T. H., Davies, W., Weninger, B., and Jöris, O. (2003). Archaeological dates as proxies for the spatial and temporal human presence in Europe: A discourse on the method. In van Andel, T. H., and Davies, W. (eds.), Neanderthals and Modern Humans in the European Landscape during the Last Glaciation, McDonald Institute for Archaeological Research, University of Cambridge, Cambridge, pp. 21-29.

Weiner, S., Xu, Q., Goldberg, P., Liu, J., and Bar-Yosef, O. (1998). Evidence for the use of fire at Zhoukoudian, China. Science 281: 251-253.

Weniger, G.-C. (1987). Magdalenian settlement pattern and subsistence in Central Europe: The southwestern and central German cases. In Soffer, O. (ed.), The Pleistocene Old World: Regional Perspectives, Plenum, New York, pp. 201-215.

White, R. (1993). Technological and social dimensions of "Aurignacian-age" body ornaments across Europe. In Knecht, H., Pike-Tay, A., and White, R. (eds.), Before Lascaux: The Complex Record of the Early Upper Paleolithic, CRC, Boca Raton, pp. 277-300.

Wiessner, P. (1983). Style and social information in Kalahari San projectile points. American Antiquity 48: 253-276.

Winterhalder, B., and Goland, C. (1993). On population, foraging efficiency, and plant domestication. Current Anthropology 34(5): 710-715.

Yellen, J. E. (1991). Small mammals: !Kung San utilization and the production of faunal assemblages. Journal of Anthropological Archaeology 10: 1-26. 